\title{
VIEWING MICROORGANISMS THROUGH THE LENSES OF REALISM
}

\author{
Abhaya Shekhar Adhikari* \\ *Masters in International Relations and Diplomacy and M.Sc. Microbiology \\ Email:avayshekhar@gmail.com
}

\begin{abstract}
The pandemic created by the Corona virus and the history of biological events have brought to the fore some sort of relation between microorganisms and state affairs. This relationship has been studied through the perspective of the realism theory of international relations. This exploratory qualitative research employed data from various literatures and assessed those data to establish a link between them. The research has confirmed that security is a link between microorganisms and realism. Microorganisms affect human health, society and state affairs and create economic and political chaos. This anomaly in state affairs is seen to jeopardize a state's security. It is established that microorganisms possess a threat for survival of the state by putting the cores of state security in peril. This research suggests that actions against these threats is a priority obligation for all states to fulfil.
\end{abstract}

Keywords: realism - microorganisms - security - international relations.

\section{INTRODUCTION}

In the pretext of the pandemic created by the Corona virus, which has hampered affairs of almost every state, the relation between viruses (representing a wide group of microorganisms) and state affairs becomes a concern for all. Biological incidents from the past have shown that these microorganisms and states do have a relation between them. Here, a predominant international relations theory that is the most widely used to understand, explain and predict state affairs in international realms has been taken to analyze the relationship between microorganisms and realism. In other words, how the realist theory views microorganisms is the scope of this study, as theories are considered to provide a framework for explaining observations. 
Realism and microorganisms represent diverse fields and connection between them seems distant. Since, realism is a theory of international relations and belongs to the academic sphere of social science and politics, it may seem completely different from the natural sciences that study microorganisms- including bacteria, virus and fungi- that can be observed only through microscopes. In brief, realism is a theory that attempts to deliver a conceptual framework in which international politics operates. It views various aspect of international politics like arms possession, foreign policy, diplomacy, resources and power through its lenses and allows us to understand and make sense of the world by explaining past state behaviors and predicting their future behaviors. However, there are very limited incidences where international theories like realism have been applied to view the havoc created by microorganisms despite their key role in a state's security. This research tries to address the gap by bringing these seemingly distant concepts together.

The question is: can the threats from microorganisms be viewed from a realistic perspective? This paper tries to find the common point that exists between microorganisms and realism and assesses the former through the lenses of realism.

\section{METHODS}

This is an exploratory qualitative research and data have been employed from secondary sources. Published literature and books were accessed to obtain the data and were then analyzed to establish a link between the variables.

\section{RESULT}

Realism and microorganisms appear unrelated in the broad sense. But, when analyzed following a certain logic they are found to be related. The analysis of various literatures shows that security is the common point that they share. According to realism, security is the primary goal of all states and microorganisms possess the ability to create a serious threat to the security of a state. Combining these two findings, the article then establishes a link between realism and microorganisms. Let us first demonstrate the perspective of realism on security before going on to see how microorganisms possess a threat to the security for a state. 


\section{Realism}

Realism establishes a theoretical framework within which states function in the international arena. This regards states as the most important players in the international system and security as their priority obligation (Antunes \& Camisão 2018). They take the view that there is no alternative in the world of self-help but to seek their own protection (Baylis 2008). States are primarily concerned about maintaining or improving their position relative to other states in terms of security (Heywood 2011). They are always aware of how much they are gaining compared with other states. The states tend to achieve their security through any means- whether by competition or cooperation.

Other states are liable to view the means they use as hostile and offensive. The other states build up their own security measures in response, since only power can be a check on power (Heywood 2011). This leads to competition between and among states towards achieving their own security.

There are realists who concentrate on cooperation to achieve security rather than competition. According to Charles Glaser, there are circumstances under which adversaries can better achieve their security goals by cooperation strategies rather than competitive ones (Baylis 2008). As the security dilemma literature suggests, in terms of security, it is oftern best to accept rough parity rather than seek maximum gains that will spark an arms race leading to less security for all in the longer term (Baylis 2008). Thus, security is a principal element of realism that sees states trying to achieve it which through any means.

\section{Security}

Security has been defined as "freedom from danger or harm", "the preservation of groups' core values" or "the absence of threats" (Bhal 2014). In a general sense, security involves a physical condition of being free from danger or harm and the psychological condition of feeling secure (Yuk-ping Lo 2015). Security is a contested concept as a major disagreement exists on the focus of enquiry, i.e., for whom and for what values security is to be provided.

Traditionally, the state security was the key concern and the main security concern and all efforts were put to attain security of the state 
(Williams \& McDonald 2018). The main interest tended to be on the military capabilities of the state to deal with threats that they faced (Baylis 2008). But recent developments started giving priorities to other objects that could also be the focus of security provisions. They were termed non-traditional security. According to some analysts, human beings should be the highest security priority, since security makes no sense without regard to individual human being (Williams \& McDonald, 2018). Another approach has focused on the concept of 'society' as the most important referent object of security studies (Baylis 2008). Similarly, a range of values has been proposed, apart from the security of the state as was traditionally done. These values include political, economic, societal and environmental (Baylis 2008). Regardless of this contestation, this article takes into account all the aspects of security, whether traditional or non-traditional.

\section{Microorganisms as security threat}

Microorganisms are microscopic creatures that include bacteria, viruses and fungi. They are ubiquitous in nature and have a close relationship with human beings. Among these microorganisms are a group that are dangerous to human beings and can cause disease, even cost their lives.

When the harmful variety of microorganisms affect a small number of people within a certain boundary, their control falls within the normal health domain that provides regular medical services to people. In contrast, whenever these microorganisms spread on a larger scale breaking the anticipated boundaries, the result could be disruptive for other domains of the state, other than regular health services. It could even become a concern for the entire gamut of state mechanisms as the spread may disrupt normal life processes of each and every individual which will eventually lead to an imbalance in the general operation of state affairs. Thus, the spread of harmful microorganisms in a large population is a security concern for the state. Such spreads can happen through various means.

Various infectious diseases have emerged at certain time intervals asa natural process. Examples of this are the H5N1 avian influenza and H1N1 swine flu, which led to a mild pandemic in 2009-2011 (Ryan 2016). Laboratories with dangerous pathogens also pose great risks to individual researchers and to local communities (Koblentz 2010). Lethal laboratoryacquired infections in members of a laboratory can also cause secondary transmissions to individuals outside of the laboratory. One example is the 
foot-and-mouth disease outbreak at several local farms following a breach at Pirbright BSL-4 laboratory in the United Kingdom in 2007 (Koblentz 2010).

Further, terrorist groups with political, religious or other ideological motive can also use these agents as an alternative to conventional weapons to achieve their goal. Such bioterrorism was witnessed during the anthrax letter attacks in 2001 (Koblentz, 2010).

Based on the history and analysis of possibilities, it can be summarized that these organisms can spread to a larger population through three different means- a natural outbreak taking the form of epidemic or pandemic, accidental release from laboratories and other facilities that handle such agents, and through deliberate release by individuals or groups.

\section{Why is management of these organisms security issue for a state?}

These organisms affect human health and society and create economic and political disruptions severely affecting state affairs. Since protection of humans and society and preservation of economic integrity and political order, in addition to the overall security of state, are the chief elements of security of any nation, these microorganisms can peril those values. These values are the core elements of state security.

The influenza pandemic of 1918-19 is estimated to have killed more than 50 million people worldwide, which is more than what World War-I killed (Koblentz 2010). The prevalence of such diseases is a natural phenomenon but their sudden spread affecting an enormous number of people creates a serious concern for the whole state prompting additional obligations to protect other healthy individuals and properly manage those already affected. Protection of citizens is a chief responsibility of a state.

In the case of adeliberate release of microorganisms against any state, which can mostly be done by other states and non-state actors like terrorist groups, it becomes a chief security concern for that state and is a breach in its sovereignty. The use of biological agents is just an alternative weapon to the traditional means of warfare for achieving their desired goals. Thus, just as traditional warfare remains a security concern for any state, the use of biological weapons also become sa security concern. Here, only the means of warfare has changed, not the end. The anthrax letter attacks in 2001 and the use of biological agents by disciples of guru Shree Rajneesh 
in Oregon (Koblentz 2010) can be an illustration. A state will secure itself through any means for the protection of its sovereignty, territorial integrity, population and other assets.

Microorganisms can also impact international relations of a state. It can bring trust issues among countries to the fore and take their relations in a negative direction. The ongoing Corona pandemic can be an example of this, as existing negatives between China and USA have amplified and their diplomatic ties have further cooled down. According to some accounts, China has blamed American soldiers for introducing the Corona virus to the local population when they visited Wuhan in October (Myers, 2020). Similarly, US president Donald Trump has alleged that the virus originated in a Chinese laboratory and has frequently termed the virus as a "Chinese Virus" (BBC, 2020).

Similarly, an infringement in the sovereignty of a state remains a possibility in case of failure to contain the spread of a deadly disease. Such possibility cannot be neglected based on the past experiences of the concepts like 'war on terror' and 'responsibility to protect', through which states had the decree to intervene in other states' internal affairs. Similarly, a new idea might be initiated that gives states the mandate to act against the spread in the sovereign land of other states.

The spread of disease in the larger population disturbs people's daily lives. A huge number of individuals thus becomes unavailable for other purposes, either because they are infected or are quarantined against the risk of infection. Financial, medical, educational and all other spheres of society deviate from normal functioning. Lack of necessary daily supplies like food and disruption in medical services can exemplify how the society dysfunctions at a such a point in time.

The daily supplies become limited, production remains low, unemployment rises, transports shut down, scarcity in the marketplace becomes rampant and prices rise. In severe cases, the resultant economic recession could be worse than what the normal business cycle usually brings about. The worst hit are the economically vulnerable, like the daily wage earners, who face a serious challenge for survival.

For a state, the recession is most pronounced in two ways- a direct impact on the functioning of the financial market and the other is the impact on the state's budgetary arrangements. The financial market can get jeopardized because of the reduction in overall production, i.e. manufacturing decline, decrease in trade activities-both national and international and dysfunction 
of other economic sectors like tourism and foreign employment, all leading to a GDP decline. Preliminary impact estimates of the 2004 avian influenza in South East Asian economies suggested that a single large outbreak could result in a reduction of up to 1.5 per cent of GDP growth (McLeod, Morgan, Prakash \& Hinri n.d.). The result can be seen in the form of a banking and financial crisis.

Similarly, regarding expenditure, the state faces a pressure in its planned spending as it needs to spend a significant proportion of the budget in treating and managing the disease and in implementing relief packages and recovery programs. The cost of the 1997 outbreak in Hong Kong, it is suggested, may have been US\$100s of millions (McLeod, Morgan, Prakash \& Hinri n.d.). Similarly, a study in 1999 suggested that an avian influenza pandemic in the US alone might cause economic losses of $\$ 100$ to $\$ 200$ billion at 2004 values (McLeod, Morgan, Prakash \& Hinri n.d.). These contingent expenditures distort the planned expenditure creating insufficiency or reduction of expenditure allocated for other sectors. Thus, the outbreak may threaten the economy of the state.

Since all state machineries become afflicted by the economic recession, the general breakdown of normalcy affects the state's responses as well. During the time of an outbreak two types of medical services are necessary. The first is the special medical services needed to fight the outbreak and the second is the routine or normal medical services. Outbreaks result in the curtailing of normal medical services as available medical resources are diverted to meet the sudden and emergent medical needs of a large number of people. The shortage of health care provisions creates panic and chaos, the control of which becomes a security concern for the state. The situation might even lead to political unrest. In the worst case scenario, groups with illegal motives can become active to create a condition of anarchy and deepen the security crisis further.

\section{CONCLUSION}

The linkage between realism and microorganisms is that microorganisms possess a threat to the security of a state-the principal element of realism. Thus, actions against such threats is a priority obligation for all states. 


\section{REFERENCES}

Antunes, S., \& Camisão, I. (2018). Introducing realism in international Relations Theory. In: E-International Relations Publishing (ed.) Beginner's textbook - international relations Theory (p. 1). https:// www.e-ir.info/pdf/72860

Baylis, J. (2008). The concept of security in international relations. In: H. Brauch (ed.) Globalization and environmental challenges. pp 495502. Springer, Berlin, Heidelberg. doi: https://doi.org/10.1007/9783-540-75977-5_37

BBC. (2020). Coronavirus: Trump stands by China lab origin theory for virus. https:/www.bbc.com/news/world-us-canada-52496098

Bhal, J. (2014). Security: An essentially contested concept? E-International Relations Student. https://www.e-ir.info/2014/08/24/security-anessentially-contested-concept/

Heywood, A. (2011). Theories of global politics. In: Palgrave Macmillan (ed.) Global politics. pp 54-60.

Koblentz, G. (2010). Biosecurity reconsidered: Calibrating biological threats and responses. International Security, 34(4). doi:10.1162/ isec.2010.34.4.96

McLeod, A., Morgan, N., Prakash, A. \& Hinri, J. (n.d.). Economic and social Impacts of Avian Influenza. FAO Emergency Centre for Transboundary Animal Diseases Operations.

Myers, S. (2020 March 13). China spins tale that the U.S. Army started the Coronavirus epidemic. The New York Times. https://www.nytimes. com/2020/03/13/world/asia/coronavirus-china-conspiracy-theory. html

Ryan, J. (2016). Biosecurity and bioterrorism. Elsevier. https://www. elsevier.com/books/biosecurity-and-bioterrorism/ryan/978-0-12802029-6

Williams, P., \& McDonald, M. (2018). Security studies: An introduction. Taylor \& Francis.

Yuk-pingLo,C.(2015). Security:ArevisedframeworkforAnalysis.HIV/AIDS in China and India. doi: https://doi.org/10.1057/9781137504210_2 